\title{
SISTEM INFORMASI GEOGRAFIS (SIG) UNTUK ZONASI \\ DAERAH BAHAYA KERUSAKAN BANGUNAN \\ AKIBAT GEMPA BUMI: \\ STUDI KASUS PADA KOTA BANDA ACEH DAN SEKITARNYA
}

\author{
Edy Irwansyah; Iqbal. S; M. Ikhsan; R. I Made Oka Yoga \\ Computer Science Department, School of Computer Science, Binus University \\ Jln. K. H. Syahdan No. 9 Palmerah Jakarta Barat 11480 \\ edirwan@binus.ac.id
}

\begin{abstract}
This study aims to develop a geographic information system software that has the ability to develop hazard area zoning of building damage due to earthquake, especially in Banda Aceh and the surrounding areas using peak ground acceleration (PGA) value approach. Analysis and design methods are implemented in this study. The analytical method consists of two stages, namely seismic data collection period 1973 - 2011 by magnitude more than 5 on the Richter scale and the calculation of earthquake acceleration on bedrock using the attenuation function of Crouse. The design method comprises several structured stages, which are designing: data flow diagram (DFD), entity relationship diagram (ERD), menus, screens, and state transition diagrams (STD). The main conclusions of this study is that a GIS -based local zoning of earthquake hazard risk can be built and developed with calculation and classification approach of the peak ground acceleration (PGA). In addition, there is a relationship significant spatial found by comparing the results with the zoning patterns of building damage in the earthquake of 2004.
\end{abstract}

Keywords: geographic information system (GIS), hazard area zoning, earthquake, peak ground acceleration (PGA), Banda Aceh

\begin{abstract}
ABSTRAK
Penelitian ini bertujuan untuk mengembangkan perangkat lunak sistem informasi geografis yang memiliki kemampuan untuk menyusun zonasi daerah bahaya kerusakan bangunan akibat gempa bumi khususnya di Banda Aceh dan sekitarnya menggunakan pendekatan nilai peak ground acceleration (PGA). Dalam penelitian digunakan metode analisis dan metode perancangan. Metode analisis terdiri dari dua tahapan, yaitu pengumpulan data kegempaan rentang waktu 1973 - 2011 dengan magnitute lebih dari 5 pada skala richter dan perhitungan percepatan gempa di batuan dasar dengan fungsi atenuase Crouse. Metode perancangan terdiri beberapa tahapan terstruktur, yaitu perancangan: data flow diagram (DFD), entity relationship diagram (ERD), menu, layar dan state transition diagram (STD). Kesimpulan utama dari penelitian ini adalah bahwa suatu zonasi daerah resiko bahaya gempa bumi berbasis SIG dapat dibangun dan dikembangkan dengan pendekatan perhitungan dan klasifikasi nilai peak ground acceleration (PGA). Selanjutnya, dengan membandingkan hasil zonasi dengan pola kerusakan bangunan akibat gempa bumi tahun 2004, terdapat hubungan spasial yang signifikan.
\end{abstract}

Kata kunci: sistem informasi geografis (SIG), zonasi daerah bahaya, gempa bumi, peak ground acceleration (PGA), Banda Aceh 


\section{PENDAHULUAN}

Sejak tahun 1900, di Indonesia tercatat telah terjadi tiga peristiwa gempa bumi besar, yaitu gempa Banda tahun 1983 dengan intensitas 8,5 skala richter, gempa Sumatera tahun 2004 dengan intensitas 9,0 skala richter dan gempa Nias tahun 2005 dengan intensitas 8,7 skala richter. Intensitas gempa bumi yang besar ini disebabkan oleh posisi kepulauan Indonesia yang secara geografis terletak di antara tiga lempeng tektonik Utama, yaitu lempeng Eurasia di utara, lempeng Indo-Australia di selatan dan lempeng Pasifik di timur laut.

Gempa bumi sebagai respon atas pergerakan lempeng selain mengakibatkan jatuhnya korban jiwa, juga berdampak pada kerusakan infrastruktur fisik. Total angka korban untuk kejadian ini di seluruh area yang tekena dampak mencapai 186,983 orang meninggal dan 42,883 orang hilang (Villverde, 2009). Di Indonesia, korban jiwa terbanyak tercatat di Aceh dan Sumatera Utara pada kejadian gempa bumi Sumatera Desember 2004 dengan jumlah korban mencapai 110.229 jiwa meninggal, 12.123 lainnya hilang dan 703.518 jiwa terpaksa mengungsi (Bappenas, 2005).

Kerusakan infrastruktur fisik yang paling dominan akibat gempa bumi adalah kerusakan pada unit bangunan baik yang diakibatkan oleh buruknya kualitas konstruksi (internal). Angka kerusakan bangunan akibat gempa bumi besar yang pernah tercatat diketahui terjadi di kota Banda Aceh tahun 2004 dengan angka kerusakan total bangunan mencapai 35 persen dari keseluruhan bangunan yang ada (Irwansyah, 2010). Kondisi yang sama juga terjadi di beberapa kota seperti 140.000 unit bangunan mengalami kerusakan total akibat gempa bumi di Yogyakarta tahun 2006 (Miura et al, 2005) dan angka kerusakan bangunan yang lebih sedikit akibat kejadian gempa Bengkulu tahun 2007.

Menyadari posisi geografis Indonesia dan fakta bahwa gempa bumi memberi dampak yang besar baik dari sisi korban jiwa dan kerusakan infrastruktur khususnya bangunan, tetapi hingga saat ini metode yang lebih tepat untuk menentukan daerah daerah rawan kerusakan bangunan akibat gempa bumi belum tersedia.

Maka dari itu, penelitian ini bertujuan mengembangkan suatu sistem informasi geografis (SIG) untuk penentuan zona bahaya kerusakan bangunan akibat gempa bumi khususnya di kota Banda Aceh dan sekitarnya dengan menggunakan pendekatan perhitungan percepatan gempa di batuan dasar (peak ground acceleration)

Pengertian sistem informasi geografis (SIG) tidak dapat dilepaskan dari beberapa pengertian seperti sistem, informasi dan sistem informasi geografis itu sendiri.

Menurut Turban et al, 2003, sistem adalah sekumpulan komponen yang saling berhubungan untuk menghasikan tujuan bersama dengan menerima sebuah input dan menghasilkan sebuah output dalam sebuah proses yang terorganisir.

Menurut Mc Leod, 2001, sistem adalah elemen-elemen yang saling terintegrasi dengan maksud yang sama dalam mencapai suatu tujuan. Dari definisi-definisi tersebut diatas, dapat disimpulkan bahwa sistem terdiri dari komponen-komponen/elemen-elemen yang saling berhubungan dan berintegrasi satu sama lain untuk menerima input, proses inputan yang ada, dan akhirnya mengeluarkan output untuk mencapai suatu tujuan.

Menurut O’Brien, 2005, sistem informasi merupakan kombinasi dari orang, perangkat keras, perangkat lunak, komunikasi jaringan, dan sumber data yang dikumpulkan, ditransformasikan, dan disebarkan informasi di dalam suatu organisasi atau perusahaan. Menurut Turban et al, 2003, sistem informasi dapat diartikan sebagai sekumpulan komponen yang saling berhubungan dalam 
mengumpulkan atau menerima, memproses, menyimpan, dan mendistribusikan informasi untuk mendukung pengambilan keputusan dalam organisasi atau perusahaan. Agar supaya sistem informasi dapat dimanfaatkan dengan efektif, maka informasi mengenai organisasi atau perusahaan, manajemen dan teknologi informasi yang membentuk sistem harus diketahui dengan pasti.

Sementara itu, geografi berasal dari bahasa Yunani, geos dan graphien. Geos yang berarti bumi atau permukaan bumi, sedangkan graphien mempunyai arti mencitrakan atau melukiskan. Melalui kata Geos dan Graphien, geografi dapat diartikan pelukisan bumi atau pencitraan bumi. Dalam arti yang luas, geografi adalah ilmu pengetahuan yang mempelajari tentang permukaan bumi, penduduk dan hubungan timbal balik antara keduanya. Permukaan bumi dalam pengertian diatas dapat diartikan sebagai daratan, air atau perairan, dan lapisan-lapisan udara. Juga dapat didefinisikan sebagai tempat berlangsungnya kehidupan mahluk hidup.

Menurut Paryono (2005), Sistem Informasi Geografis (SIG) adalah suatu sistem yang berbasiskan komputer yang digunakan untuk menyimpan, memanipulasi, dan menganalisis informasi geografis. Teknologi ini berkembang pesat sejalan dengan perkembangan teknologi informatika atau teknologi komputer. Secara umum, Sistem Informasi Geografis (SIG) dapat didefinisikan sebagai suatu sistem berbasis komputer yang dapat memanajemen, memanipulasi, menganalisis informasiinformasi kebumian dan menampilkan keluaran / output informasi geografis berikut data dan atributatributnya. Komponen-komponen SIG, sebagai suatu sistem berbasiskan komputer termasuk perangkat keras, perangkat lunak, data atau informasi, dan juga operator yang mengoperasikan serangkaian proses manipulasi

Selanjutnya, gempa bumi adalah peristiwa bergetarnya bumi akibat pelepasan energi di dalam bumi secara tiba-tiba yang ditandai dengan patahnya lapisan batuan pada kerak bumi. Akumulasi energi penyebab terjadinya gempa bumi dihasilkan dari pergerakan lempeng-lempeng tektonik (BMKG, 2010). Gempa bumi dengan magnitude cukup besar (> 5,9 skala Richter) mampu merusakkan bangunan melalui dua cara, yaitu dengan cara langsung dari getaran yang memberikan efek gaya horisontal, dan secara tidak langsung melalui liquefaction (Kramer, 1996)

Menurut Villavarde (2009), penyebab terjadinya gempa bumi dapat disebabkan oleh adanya: (1) tectonic force yang berkaitan erat dengan pembentukan patahan (fault), sebagai akibat langsung dari interaksi antar lempeng pembentuk kulit bumi; (2) gempa vulkanik yang berkaitan dengan aktivitas gunung api; (3) Jatuhan atau runtuhan massa batuan/tanah yang berukuran besar; (4) ledakan konvensional dan nuklis; (5) dampak tumbukan meteorit. Penyebab gempa akibat peristiwa vulkanik, jatuhan/runtuhan massa batuan, ledakan konvensional dan nuklir serta dampak meteorit relatif jarang terjadi serta hanya berdampak pada daerah yang terbatas.

Informasi mengenai karakteristik percepatan di batuan dasar akibat gempa bumi (earthquake ground motion) dapat diperoleh melalu rekaman kejadian gempa pada masa yang lalu. Rekaman akselerasi ini dapat diintegrasikan dengan waktu untuk mengetahui sejarah ground velocity dan ground displacement. Dari perekaman ground acceleration dimungkinkan untuk mengekstraksi karakterisrik utama dari rekaman ground motion seperti peak ground velocity, peak ground displacement, ground motion duration dan peak ground acceleration (PGA) (Villavarde, 2009). Percepatan gempa (ground velocity) dapat dihitung sebagai percepatan di batuan dasar (ground acceleration) maupun percepatan gempa di permukaan tanah. Percepatan gempa di batuan dasar (PGA) dapat dihitung dengan mempergunakan fungsi antenuase. Fungsi atenuase adalah suatu fungsi yang menggambarkan korelasi antara intensitas gerakan tanah setempat (a), Magnitude gempa (M), serta jarak dari suatu titik dalam daerah sumber gempa (r). Para ahli geoteknik telah banyak merumuskan fungsi atenuase. Fungsi atenuase yang berlaku di suatu tempat belum tentu dapat berlaku di tempat yang lain, karena fungsi atenuase sangat tergantung pada kondisi alam di suatu tempat (Mabrur, 2009). Ada dua jenis rumus fungsi atenuase, yaitu fungsi atenuase Joyner \& Boore dan fungsi atenuase Crouse. Untuk menentukan percepatan gempa di batuan dasar secara teliti, maka 
perhitungan fungsi atenuase ini harus dilakukan pada seluruh kejadian gempa. Perubahan percepatan gempa di batuan dasar akan berpengaruh langsung pada percepatan gempa di permukaan tanah.

\section{METODE}

Metodologi yang digunakan dalam penulisan ini meliputi metode analisis dan metode perancangan. Metode analisis terdiri dari dua tahapan, yaitu tahapan pengumpulan data dan peta, serta tahapan pengolahan data. Data dan peta yang digunakan dalam penelitian adalah data kegempaan wilayah Banda Aceh dan sekitarnya dalam rentang waktu tahun 1973 - 2011 dengan magnitute > 5 skala richter (gempa merusak) yang bersumber dari Badan Meteorologi Klimatologi dan Geofisika (BMKG) dengan jarak sumber gempa $500 \mathrm{~km}$ dari daerah penelitian sebagaimana penelitian Sengara, 2008. Sebaran data titik titik sumber gempa yang digunakan dalam penelitian ini dapat dilihat pada Gambar 1.

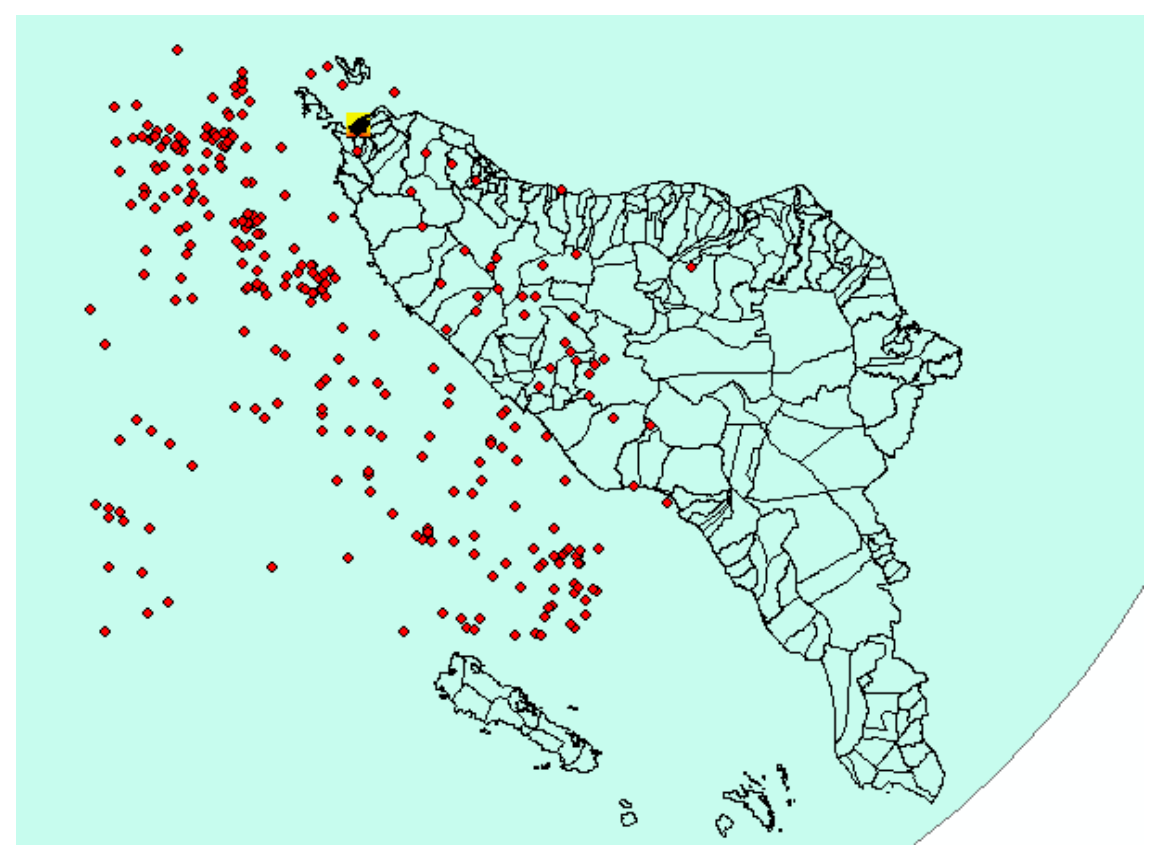

Gambar 1. Distribusi sumber gempa yang digunakan sebagai data penelitian.

Data kegempaan diperlukan untuk menghitung nilai percepatan gempa dibatuan dasar/peak ground acceleration (PGA). Percepatan gempa dibatuan dasar dapat dihitung dengan menggunaan fungsi atenuase. Fungsi atenuase adalah suatu fungsi yang menggambarkan korelasi antara intensitas gerakan tanah setempat, magnitude gempa dan jarak suatu titik dalam daerah sumber gempa. Pada penelitian ini digunakan fungsi atenuase Crouse untuk menghitung nilai percepatan gempa (PGA). Formula dan fungsi atenuase Crouse dapat dijabarkan sebagai berikut:

di mana:

$$
\ln (\mathrm{PGA})=6.36+1.76-2.73 \ln \left(\mathrm{R}+1.58 \mathrm{e}^{(0.068 \mathrm{M})}+0.0091 \mathrm{~h}\right)
$$

PGA = Peak Ground Acceleration, gal

$\mathrm{R}=$ Jarak Hipocenter, $\mathrm{KM}=$

$\mathrm{M}=$ Momen Magnitude Gempa

$\mathrm{H}=$ Kedalaman Focus $(\mathrm{Km})$ 
Perhitungan PGA akan dilakukan untuk setiap titik pada area 1000 x 1000 meter (gridding sistem) (Gambar 2) meliputi seluruh daerah penelitian di kota Banda Aceh dan Sekitarnya. Perhitungan akan dilakukan dengan bantuan perangkat lunak SIG.

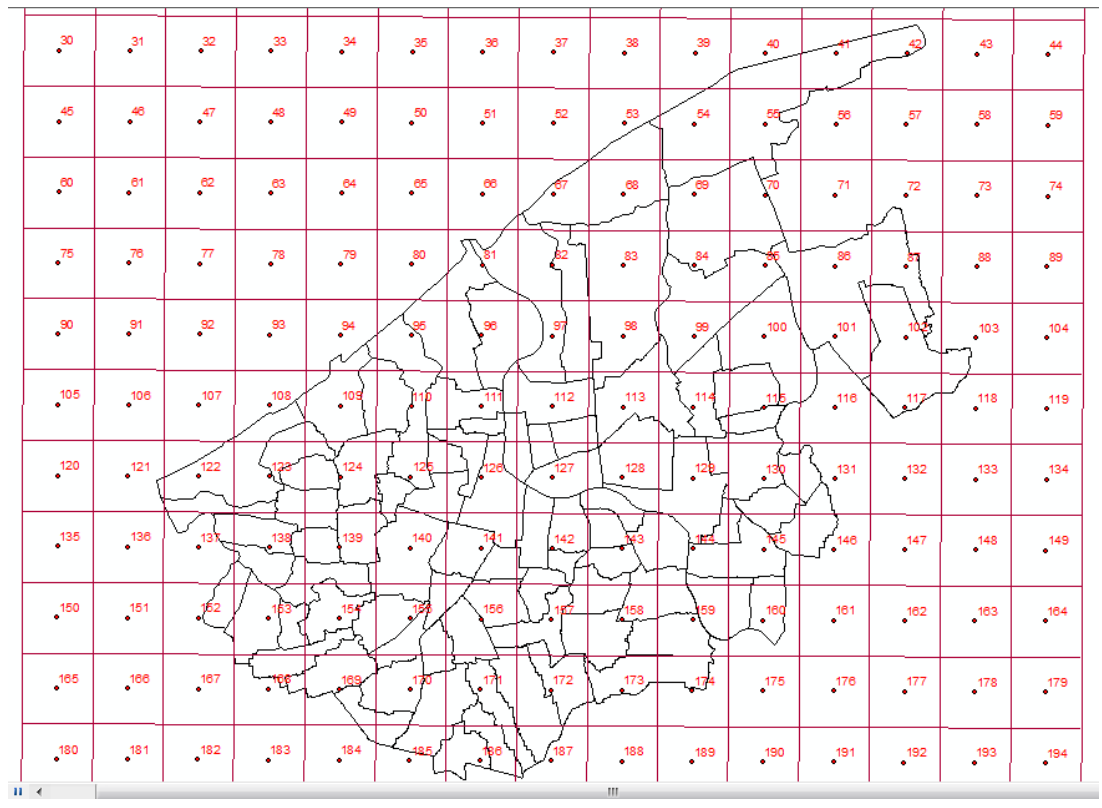

Gambar 2. Distribusi grid 1000 x 1000 meter dan titik tengah grid.

Zonasi nilai PGA dibuat dengan metode interpolasi menggunakan algoritma kriging. Peta zonasi nilai PGA akan terbagi dalam beberapa nilai klas yang berpengaruh pada penyusunan model analisa spasial. Metode perancangan yang dilakukan dalam penelitian ini adalah perancangan melalui beberapa tahapan yang terstruktur, yaitu perancangan data flow diagram (DFD), perancangan entity relationship diagram (ERD), perancangan menu, perancangan layar dan perancangan State Transition Diagram (STD).

\section{HASIL DAN PEMBAHASAN}

Aplikasi SIG yang dikembangkan dalam penelitian ini memiliki empat fungsionalitas utama, yaitu fungsi untuk penambahan data gempa baru berupa lokasi dan magnitude gempa, fungsi perhitungan jarak dari sumber gempa ke pusat pusat grid di kota Banda Aceh, fungsi perhitungan percepatan gempa dibatuan dasar/peak ground acceleration (PGA) serta penentuan zona (zonasi) daerah resiko bahaya gempa. Untuk melakukan penambahan titik gempa baru, pengguna dapat menggunakan fungsi ' $G$ o To XY' pada aplikasi dengan terlebih dahulu memasukkan koordinat titik terjadinya gempa baru. Setelah melakukan pengisian koordinat titik gempa baru, pengguna dapat melihat hasil penambahan data tersebut dan dapat ditampilkan di aplikasi dengan menggunakan fungsi 'Add Point'.

Setelah titik gempa baru tampil di dalam peta, pengguna harus menambahkan atribut tentang gempa tersebut diantaranya adalah tanggal kejadian gempa, waktu gempa, magnitude gempa dan kedalaman gempa tersebut. Untuk menambahkan atribut gempa, pengguna cukup menekan tombol menu 'Tambah Titik Gempa Baru'. Seluruh proses penambahahan (update) data gempa terbaru terhubung langsung dengan sistem basisdata (database). 
Pengguna aplikasi dapat melakukan perhitungan jarak antara dua titik dengan menggunakan fungsi 'hitung jarak'. Hasil perhitungan jarak dibutuhkan untuk menghitung nilai PGA dalam tahap selanjutnya. Proses perhitungan jarak dilakukan dengan menghitung jarak seluruh titik gempa termasuk titik gempa baru dengan seluruh titik pusat grid dalam peta. Dari hasil perhitungan tersebut, akan dipilih nilai jarak terdekat dari seluruh grid tersebut. Seluruh perhitungan dilakukan secara otomatis di dalam sistem, hasil perhitungan tidak ditampilkan setelah perhitungan selesai, tapi dapat dilihat pada tabel atribut titik grid. Hasil perhitungan jarak tersebut akan berubah menyesuaikan titik gempa baru.

Setelah perhitungan jarak, tahap selanjutnya dari keseluruhan proses adalah perhitungan nilai PGA. Perhitungan nilai PGA dilakukan menggunakan fungsi atenuase Crouse dengan formula sebagaimana dijelaskan pada metodologi. Perhitungan nilai PGA dilakukan pada modul terpisah menggunakan fasilitas Field Calculator yang tersedia di perangkat lunak ArcGIS. Keseluruhan hasil perhitungan nilai PGA selanjutnya diintegrasikan ke dalam basisdata aplikasi sebagaimana dapat dilihat pada Gambar 3. Hubungan antar entitas dalam basisdata digambarkan dalam sebuah digram relasi sebagaimana dapat dilihat pada Gambar 4.

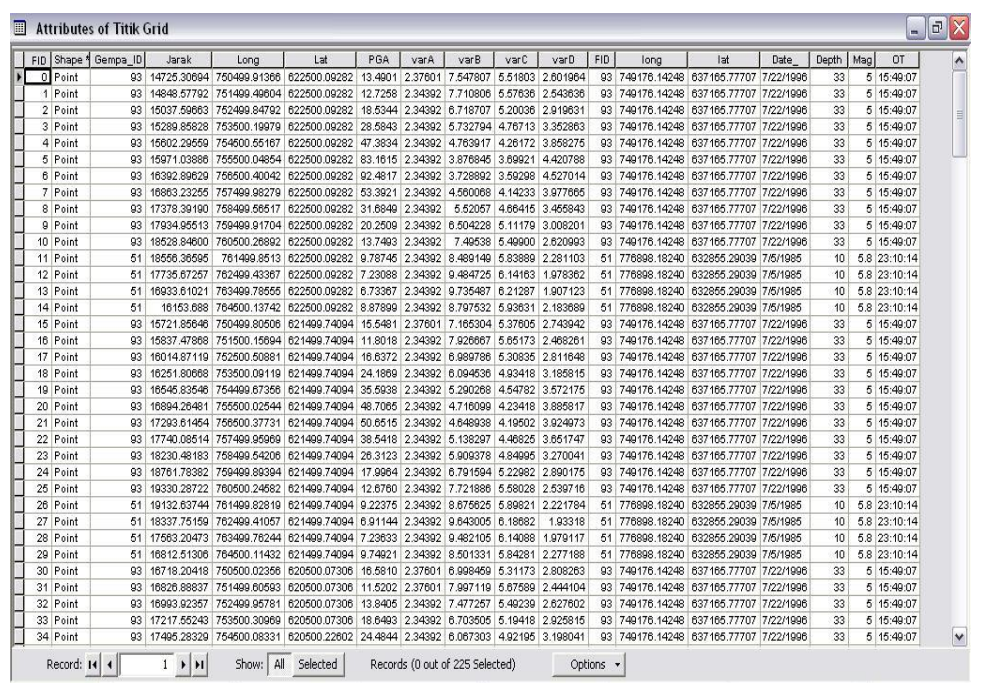

Gambar 3. Tampilan basisdata pada aplikasi.

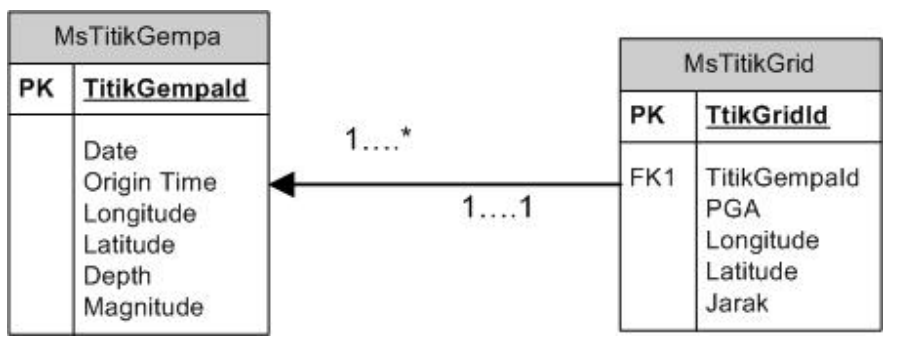

Gambar 4. Entity relationship diagram (ERD) yang menggambarkan hubungan antar entitas data dalam basisdata.

Setelah perhitungan PGA selesai, pengguna dapat menjalankan menyusun zonasi dengan menjalankan fungsi 'Zonasi Peta' pada aplikasi yang tersedia. Sistem akan melakukan zonasi secara otomatis berdasarkan hasil perhitungan PGA. Distribusi zona (zonasi) daerah resiko gempa bumi di kota Banda Aceh dan sekitarnya adalah sebagaimana dapat dilihat pada Gambar 5. 


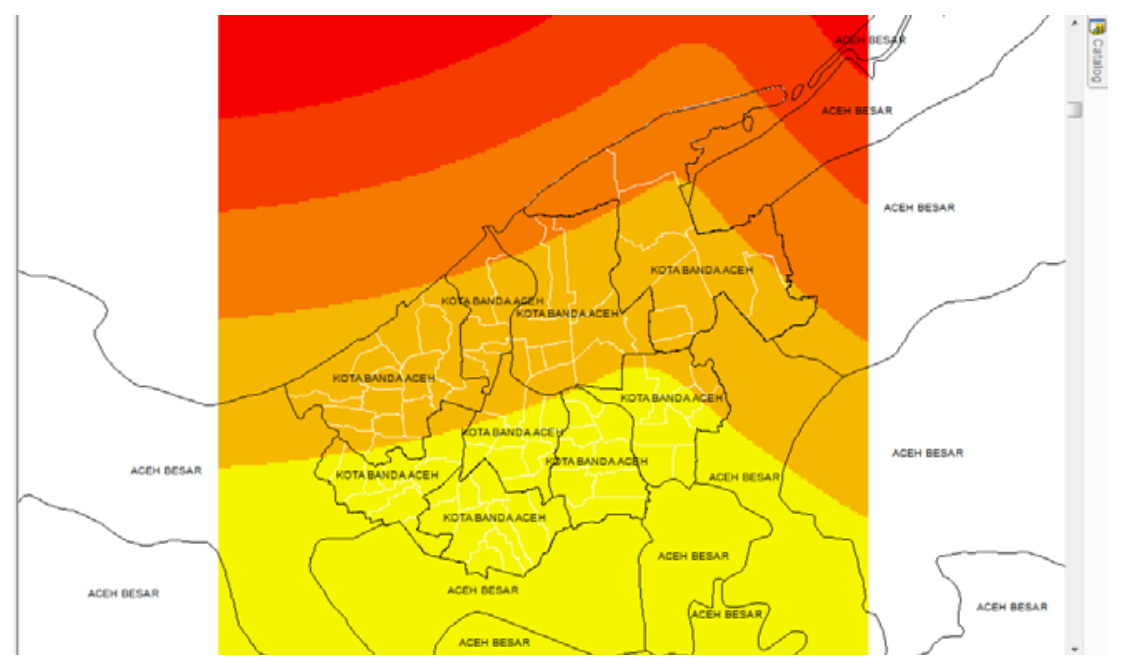

Gambar 5. Distribusi zona resiko bahaya gempa bumi di Banda Aceh berdasarkan nilai PGA.

Perbedaan warna dalam peta hasil menunjukan adanya berbedaan zona bahaya berdasarkan nilai PGA dalam rentang nilai tertentu. Hasil zonasi menunjukan bahwa kota Banda Aceh dan sekitarnya terdiri dari tiga zona tingkat bahaya gempa bumi yaitu zona I dengan nilai PGA dalam rentang 0.25 - 0.4, zona II dengan nilai PGA 0.4 - 0,58 dan zona III dengan nilai PGA $0.58-0,78$. Zonasi tersebut secara spasial menunjukan pola yang relatif paralel dengan garis pantai kota Banda Aceh.

Penelitian terdahulu dengan metode site sampling and measurement yang dilakukan oleh Sengara, (2008) di spesifik lokasi di Kecamatan Meuraxa (salah satu kecamatan di Kota banda Aceh) menunjukan bahwa PGA di daerah tersebut antara 0.325 hingga 0.40 gal dengan tiga microzona ,yaitu zona tanah keras (hard soil) dengan nilai PGA 0.325, zona tanah menengah (medium soil) dengan nilai PGA 0.325 hingga 0.375 dan zona tanah lembut (soft soil) dengan nilai PGA 0,375 hingga 0.40 gal. Perbandingan nilai zona pada daerah yang sama (Kecamatan Meuraxa) antara hasil penelitian ini dengan nilai yang dihasilkan pada penelitian Sengara (2008) menunjukan Zonasi dengan nilai PGA yang relatif mendekati, dimana sebagian besar Kecamatan Meuraxa merupakan daerah dengan zona nilai PGA berkisar $0.4-0.58$ gal dan sebagian kecil daerah di Selatan termasuk zona dengan nilai PGA berkisar $0.25-0.4$ gal. Keseluruhan nilai zona di kecamatan tersebut berkisar $0.25-0.58$ gal. Perbandingan zonasi kedua hasil penelitian adalah sebagaimana dapat dilihat pada Gambar 6.

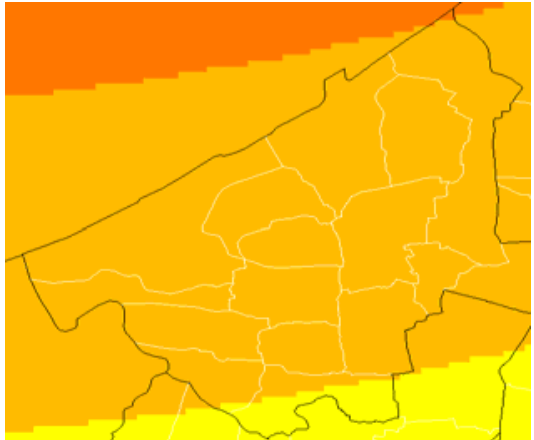

(a)

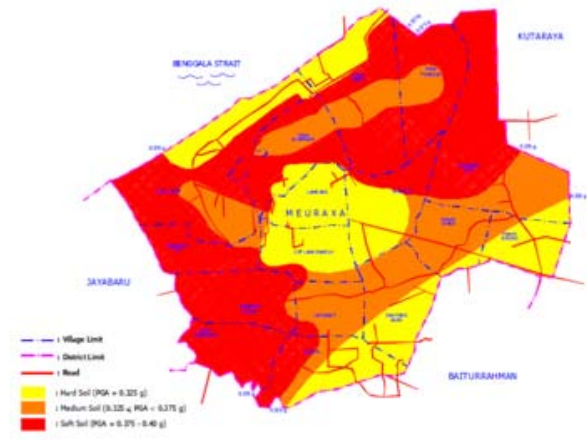

(b)

Gambar 6. PGA Zonation Comparison in Meuraxa sub-district. 
Using Atenuase Crouse (a) and Onsite-Seismic Classification by Sengara, 2008 (b). Fakta yang menarik dari hasil zonasi ini jika kita bandingkan antara pola bangunan yang mengalami kerusakan total pada kejadian Gempa Sumatera, 2004 (Irwansyah, 2010) adalah bahwa sebagian besar bangunan yang mengalami kerusakan total tersebut secara spasial terletak pada zona II dan III dengan rentang nilai PGA relative besar berkisar $0.4-0.78$ gal. Penelitian yang dilakukan oleh Supriatna et al, 2010 di daerah Sukabumi Jawa Barat menunjukan hubungan yang sama antara tingginya nilai PGA dan dampak kerusakan bangunan yang ditimbulkan pada kejadian gempa bumi. Dibutuhkan penelitian lanjutan untuk mengamati hubungan empiris antara zona nilai PGA dan parameter kebumian lainnya pada dampak yang mungkin ditimbulkan jika terjadi gempa bumi pada daerah tersebut khususnya pada tingkat kerusakan bangunannya. Hubungan antara zonasi PGA dan pola kerusakan total bangunan akibat gempa bumi dapat dilihat pada Gambar 7.

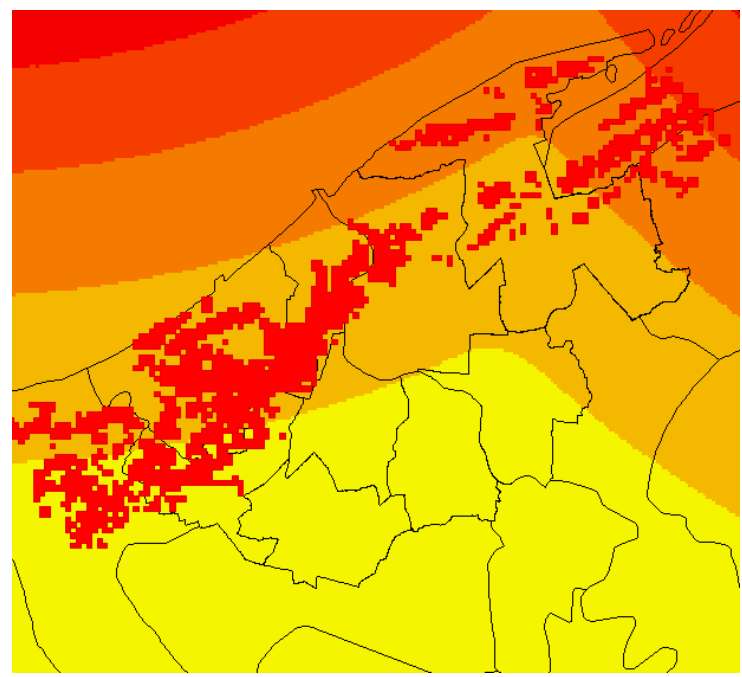

Gambar 7. Overlay zonasi PGA dan distribusi bangunan dengan tingkat kerusakan total di k Banda Aceh.

\section{PENUTUP}

Berdasarkan tujuan penelitian, beberapa kesimpulan dapat diambil yaitu: (1) SIG yang dikembangkan memiliki kemampuan untuk mengelola, menampilkan informasi histori kegempaan di wilayah Kota Banda Aceh dan sekitarnya periode tahun 1974-2011; (2) zonasi daerah resiko bahaya gempa bumi berbasis sistem informasi geografis dapat dibangun dengan dengan pendekatan perhitungan dan klasifikasi nilai peak ground acceleration (PGA); (3) sistem memungkinkan update zonasi nilai PGA berdasarkan kejadian/penambahan data gempa terbaru pada radius $500 \mathrm{~km}$ dari pusat Kota Banda Aceh dan sekitarnya; (4) Terdapat hubungan spasial yang signifikan antara pola kerusakan total bangunan pada gempa sumatera tahun 2004 dengan zonasi nilai PGA yang relatif besar.

\section{DAFTAR PUSTAKA}

Badan Perencanaan dan Pembangunan Nasional (Bappenas). (2005). Preliminary damage and loss assessment. Natural Disaster -the December 26, 2004. Jakarta: Government Printer. 
BMKG.

(2010).

Gempa

Bumi.

Diakses

dari http://www.bmkg.go.id/BMKG_Pusat/Geofisika/gempabumi.bmkg

Crouse, C. B. (1991). Ground-motion attenuation equations for earth- quakes on the Cascadia subduction zone. Earthquake Spectra, 7, 210-236.

Irwansyah. E. (2010). Building damage assessment using remote sensing, aerial photograph and gis data: case study in banda aceh after sumatera earthquake 2004. Proceeding of The 11th Seminar on Intelligent Technology and Its Application-SITIA 2010, 11, 57.

Mabrur. (2009). Analisa Potensi Likuifaksi Pada Area Apron Bandar Udara Medan Baru. (Tidak diterbitkan). Universitas Sumatera Utara, Medan.

McLeod, Raymond. (2001). Sistem Informasi Manajemen (jilid ke-1). Jakarta: Prehallindo.

Miura, H., Wijeyewickrema, A. \& Inoue, S. 2005. Evaluation of Tsunami Damage in the Eastern Part of Sri Lanka due to the 2004 Sumatra Earthquake using High-Resolution Satellite Images. Proceeding of the 3rd International Workshop on Remote Sensing for Post-Disaster Response. Diakses Sep.13, 2005dari: http://ares.tu.chiba-u.jp/workshop/ChibaRS2005/Paper Miura.pdf.

O’Brien, James. A. (2005). Introduction to Information Systems, (12 Edition). New York:.Mc GrawHill.

Paryono. (2005). Sistem Informasi Geografis, (edisi pertama). Yogyakarta: Andi Office.

Sengara, I.W. (2008). Seismic hazard and microzonation for a district in banda aceh city post 2004 great sumatra earthquake. Proceeding 14Th World Conference on Earthquake Engineering October 12-17, 2008, Beijing, China.

Supriatna, Jarot, M.S., Corry, N. (2010). Peak ground acceleration (PGA) of destructive earthquake in cimandiri fault, Sukabumi, West Java. Proceeding MapAsia 2010 and ISG 2010, Kuala Lumpur Malaysia

Turban, E., Rainer, R.kelly Jr., Potter, R. E. (2003). Introduction to Information Technology (2nd edition). New York: John Wiley \& sons.

Villaverde. R. (2009). Fundamental Concepts of Earthquake Engineering. CRC Press-Taylor and Francis Group, Boca Raton, FL, USA. 